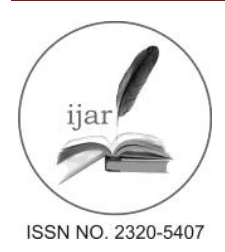

Journal homepage: http://www.journalijar.com
Journal DOI: $10.21474 /$ JAR01
INTERNATIONAL JOURNAL
OF ADVANCED RESEARCH

Journal DOI: 10.21474/IJAROI

RESEARCH ARTICLE

\title{
BIOFORTIFICATION: AN ALTERNATIVE FOR ZINC AND IRON DEFICIENCY IN CEREALS - A REVIEW.
}

\author{
*Sooraj Chandra Pankaj ${ }^{1}$ and Pradeep Kumar Dewangan ${ }^{2}$ \\ 1. Ph.D. (Scholar), Department of Agronomy, Birsa Agricultural University, Ranchi-834006 Jharkhand, India. \\ 2. M.Sc. (Ag.), Department of Agronomy, Birsa Agricultural University, Ranchi-834006 Jharkhand, India.
}

\section{Manuscript Info}

Manuscript History:

Received: 18 March 2016

Final Accepted: 29 April 2016

Published Online: May 2016

Key words:

*Corresponding Author

Sooraj Chandra Pankaj.

\begin{abstract}
Iron and zinc deficiencies in human nutrition are widespread in developing Asian and African countries where cereal grains are the staple food. Effects are therefore underway to develop cereal genotypes with grains denser in $\mathrm{Fe}$ and $\mathrm{Zn}$ by traditional plant breeding or using genetic engineering techniques. This approach requires a long period and adequate funds. However, the products of genetic engineering are not well accepted in many countries. Also, there is a trade-off between yield and grain biofortification. Agronomic biofortification offers to achieve this without sacrificing on yield and with no problem of product acceptance. From the viewpoint of biofortification, foliar application has been reported to be better than the soil application of $\mathrm{Fe}$ and $\mathrm{Zn}$, and for this purpose, chelated Fe and $\mathrm{Zn}$ fertilizers are better. When soil applied, water soluble sources of $\mathrm{Zn}$ are better. Soil application of $\mathrm{Fe}$ is not recommended. Agronomic biofortification depends upon management practices (tillage, water management, nutrient interactions), soil factors (amounts present, $\mathrm{pH}$, mechanisms of $\mathrm{Zn}$ fixation other than $\mathrm{pH}$ ), and plant factors (root characteristics, excretion of phytosiderophores and organic acids by roots, $\mathrm{Zn}$ utilization at the cellular level, translocation within plant and mechanisms of $\mathrm{Zn}$ accumulation in grain). Genetic and agronomic biofortification are complementary to each other. Once the genotypes having denser grains are developed, they will have to be adequately fertilized with $\mathrm{Fe}$ and $\mathrm{Zn}$.
\end{abstract}

Copy Right, IJAR, 2016. All rights reserved.

\section{Introduction:-}

Cereals are staple food in most developing low-income countries of Asia and Africa, where they may contribute as much as 60\% of the dietary energy (Prasad et al., 2014). Dietary deficiency of essential micronutrients such as zinc (Zn) and iron (Fe) affects more than two billion people worldwide (White and Broadley, 2009), mostly pregnant women and children below the age of five year, who suffer from severe acute malnutrition. In many parts of the world, micronutrient deficiency is a more widespread problem than poor dietary quality and low energy intake (Stewart et al., 2010). Rice, the main staple food of Asia, is inherently very low in $\mathrm{Zn}$ and its high consumption relative to other foods contributes to high incidence of $\mathrm{Zn}$ deficiency in human populations in Asia (Phattarakul et al., 2012). Iron (Fe) deficiency alone affects > 47\% of all pre-school aged children globally, often leading to impaired physical growth, mental development and learning capacity. Zinc (Zn) deficiency, like iron, is thought to affect billions of people, hampering growth and development and destroying immune systems (Cakmak et al., 2010).

Mineral malnutrition can be addressed through dietary diversification, mineral supplementation, food fortification and/or increasing mineral concentrations in edible crops (biofortification) (Hussain et al., 2010). Agronomic biofortification is of great importance in enriching seeds with $\mathrm{Zn}$ and Fe. Soil applications are reported to have, in general, small increases in grain $\mathrm{Zn}$ concentration, while foliar applications result in remarkable increases in grain 
Zn concentration in wheat (Cakmak et al., 2010). Hari Ram et al (2015) showed that application of foliar Zn at tillering and milk stages proved beneficial in increasing grain $\mathrm{Zn}$ content in both rice and wheat. Zinc fertilization improved grain yield and $\mathrm{Zn}$ content of maize hybrids compared to synthetic variety (Kanwal et al., 2010).

Foliar application of $\mathrm{FeSO}_{4} .7 \mathrm{H}_{2} \mathrm{O}$ at 0.5 and $1 \%$ levels at different growth stages of rice crop significantly increased grain yield and Fe concentration in rice grains. Five rice cultivars showed differential response to yield, concentration and uptake of Fe with its foliar spray (Singh et al., 2013). Aciksoz et al., (2011) revealed that inclusion of urea in foliar Fe fertilizers had a positive impact on grain Fe concentration in wheat. The combined application of $\mathrm{Zn}$ as seed priming $(2.0 \%)$ and foliar spray (2.0\%) can improve the performance of maize hybrids (Mohsin et al., 2014).

\section{Effect of zinc deficiency:-}

Prasad et al., (2013) Data on global mortality in children under 5 years of age due to different micronutrient deficiencies in 2013 (Table 1). Zn deficiency was next only to vitamin A deficiency and was responsible for over 453 thousand deaths.

Table: 1. Global mortality in children under 5 years of age.

\begin{tabular}{|c|c|}
\hline Deficiency & Deaths \\
\hline Vitamin A & 666,771 \\
\hline Zinc & 453,207 \\
\hline Iron & 20,854 \\
\hline Iodine & 3,619 \\
\hline
\end{tabular}

Cakmak et al., (2008) According to a WHO report on the risk factors responsible for development of illnesses and diseases, $\mathrm{Zn}$ deficiency ranks $11^{\text {th }}$ among the 20 most important factors in the world and $5^{\text {th }}$ among the 10 most important factors in developing countries (Table 2).

Table: 2. Ten leading causes of illness and disease in low income countries.

\begin{tabular}{|l|c|}
\hline Risk factors & Illness (\%) \\
\hline Underweight & 14.9 \\
\hline Unsafe sex & 10.2 \\
\hline Unsafe water & 5.5 \\
\hline Indoor smoke & 3.7 \\
\hline Zinc deficiency & 3.2 \\
\hline Iron deficiency & 3.1 \\
\hline Vitamin A deficiency & 3.0 \\
\hline Blood pressure & 2.5 \\
\hline Tobacco & 2.0 \\
\hline Cholesterol & 1.9 \\
\hline
\end{tabular}

Alloway et al., (2004) The regions with Zn-deficient soils are also the regions where $\mathrm{Zn}$ deficiency in human beings is widespread, for example in India, Pakistan, China, Iran and Turkey Figure 1 shows global distribution of the regions where $\mathrm{Zn}$ deficiency problem has been reported in crop plants. Possibly, there are many other regions or countries where $\mathrm{Zn}$ deficiency problem has not been reported or diagnosed.

Fig: 1. Global soil and zinc deficiency.

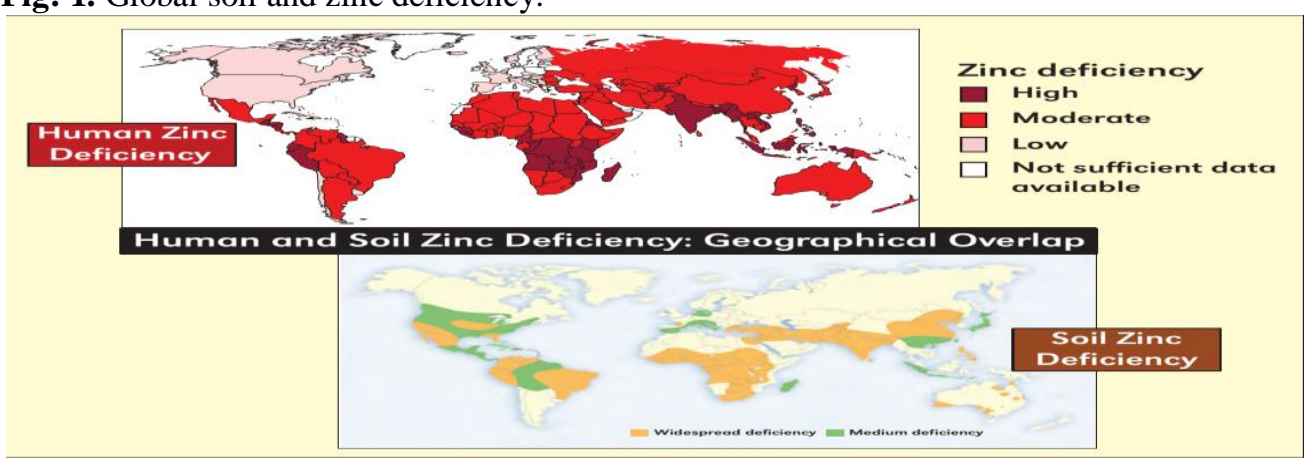


White and Broadley et al., (2005). Traditional interventions tackled mineral malnutrition by supplementation, food fortification and dietary diversification. None of these have been universally successful on sustainable basis because they require safe delivery systems, stable political policies, appropriate social infrastructures and continued investment for longer periods (Table 3). Fageria, (2008) Conventional crop breeding (especially hybrid development), molecular biology, genetic engineering and resource management can greatly help in enhancing the crops to feed the poor (Fig. 2).

Table: 3. Possible solution to mineral deficiency in human population.

\begin{tabular}{|l|l|l|}
\hline Intervention & Scope & Economics \\
\hline Supplementation & $\begin{array}{l}\text { It is generally recommended during } \\
\text { pregnancy or in severe Zn } \\
\text { deficiency for a shorter period. }\end{array}$ & $\begin{array}{l}\text { It is costly and only recommended } \\
\text { when a very quick response is } \\
\text { required. }\end{array}$ \\
\hline Fortification & $\begin{array}{l}\text { It is effective but limited to urban } \\
\text { areas. }\end{array}$ & $\begin{array}{l}\text { It is very uneconomical if carried } \\
\text { out for longer period of times. }\end{array}$ \\
\hline $\begin{array}{l}\text { Food Diversification/ } \\
\text { modification }\end{array}$ & $\begin{array}{l}\text { It is applicable only where } \\
\text { alternative food products are } \\
\text { available with high adoptability. }\end{array}$ & $\begin{array}{l}\text { It is economically feasible and } \\
\text { sustainable intervention. }\end{array}$ \\
\hline Bio-fortification & It is targeted and reachable & $\begin{array}{l}\text { It is cost effective and sustainable } \\
\text { approach. } \\
\text { It has added benefit of yield } \\
\text { increase on Zn deficient soils and } \\
\text { seems permanent solution. }\end{array}$ \\
\hline
\end{tabular}

Fig: 2. Approaches for zinc biofortification of staple food grains.

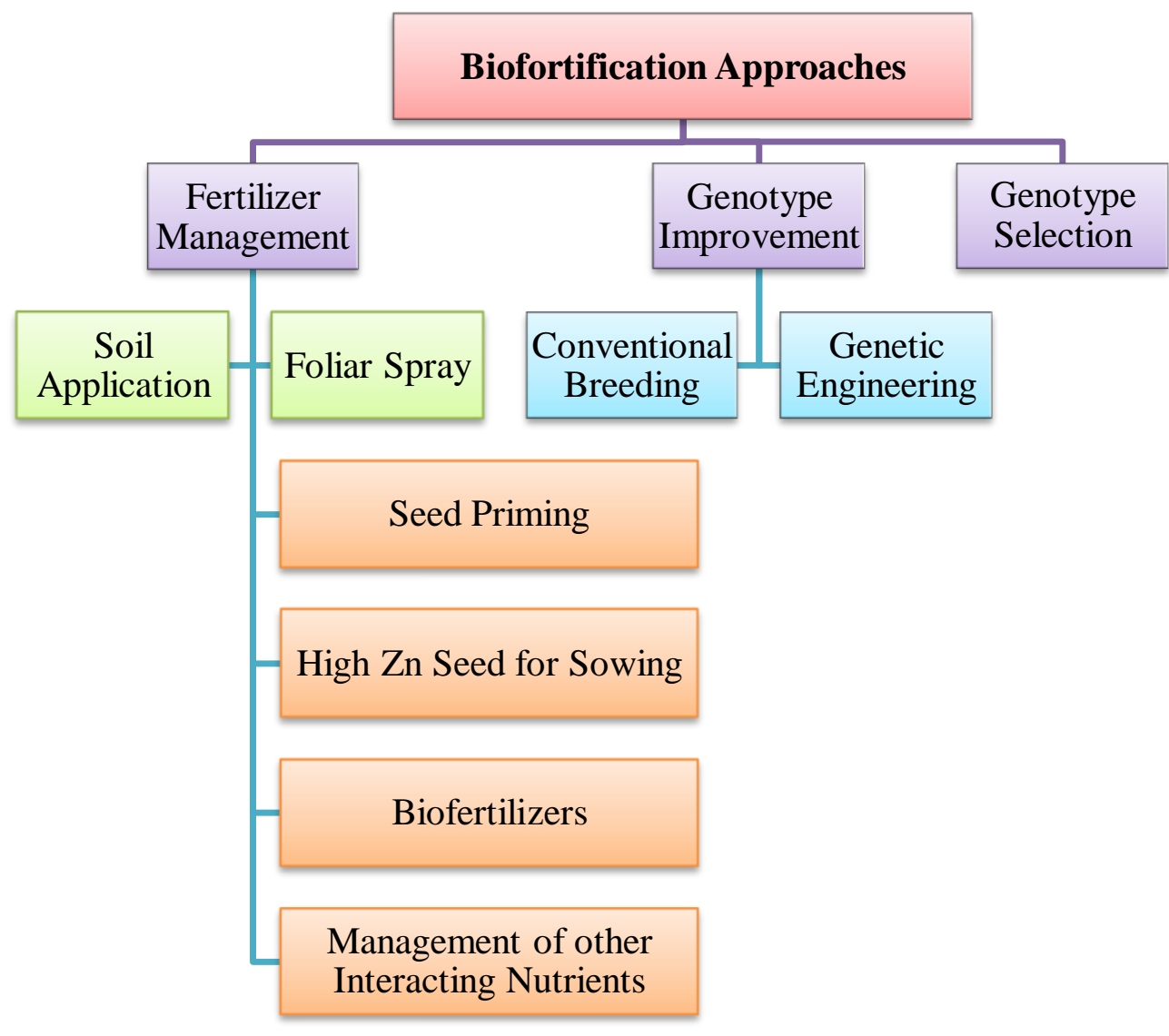


Wei et al., (2012) found that regardless of cultivar, although polishing process decrease substantial amount Zn from mature grain, the polished rice obtained from foliar $\mathrm{Zn}$ applications was still contained 10.22-24.04\% more $\mathrm{Zn}$ than those of control (Fig. 3) Similar trends were found in polished rice (Fig. 3), the cultivar Biyuzaonuo had the highest $\mathrm{Zn}$ concentration, while Hai7 had the lowest $\mathrm{Zn}$ concentration in all $\mathrm{Zn}$ treatments.

Fig: 3. Effect of different forms of foliar application on $\mathrm{Zn}$ concentration in white rice grain.

\section{Effect of different forms of foliar $\mathrm{Zn}$ fertilization on $\mathrm{Zn}$ concentration in white rice grain}
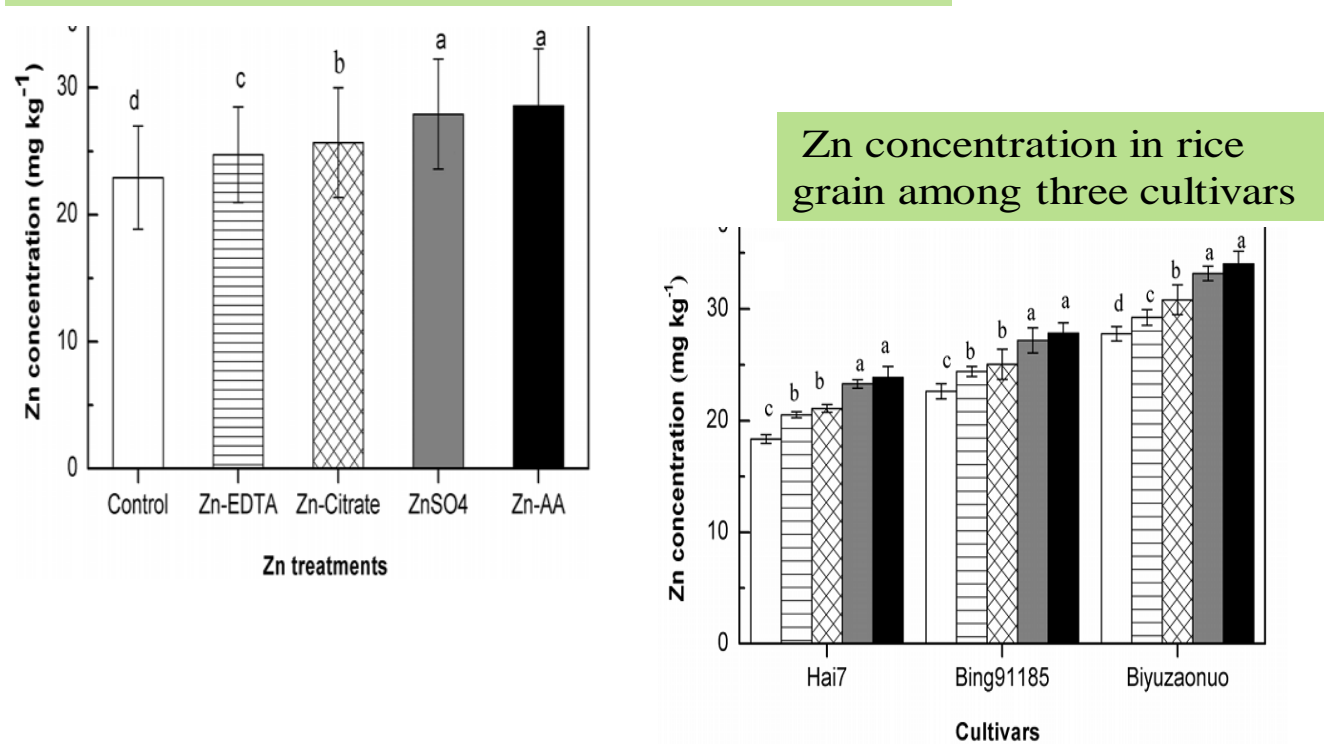

Singh and Prasad, (2014) agronomic biofortification is a win-win approach for developing countries which relies on exploitation of micronutrient dense cultivar applying zinc fertilizers to seeds, soil and/or foliar, at rates greater than those required for maximum yield, in order to increase the uptake of $\mathrm{Zn}$ into the plants and its translocation into seeds. This could be a more sustainable and cost effective strategy to improve $\mathrm{Zn}$ concentrations in rice grains. Application of soil microorganism and selection of suitable crop rotation has also been found very promising to increase zinc concentration in rice grain (Fig. 4).

Fig: 4. Major approach for agronomic bio-fortification .

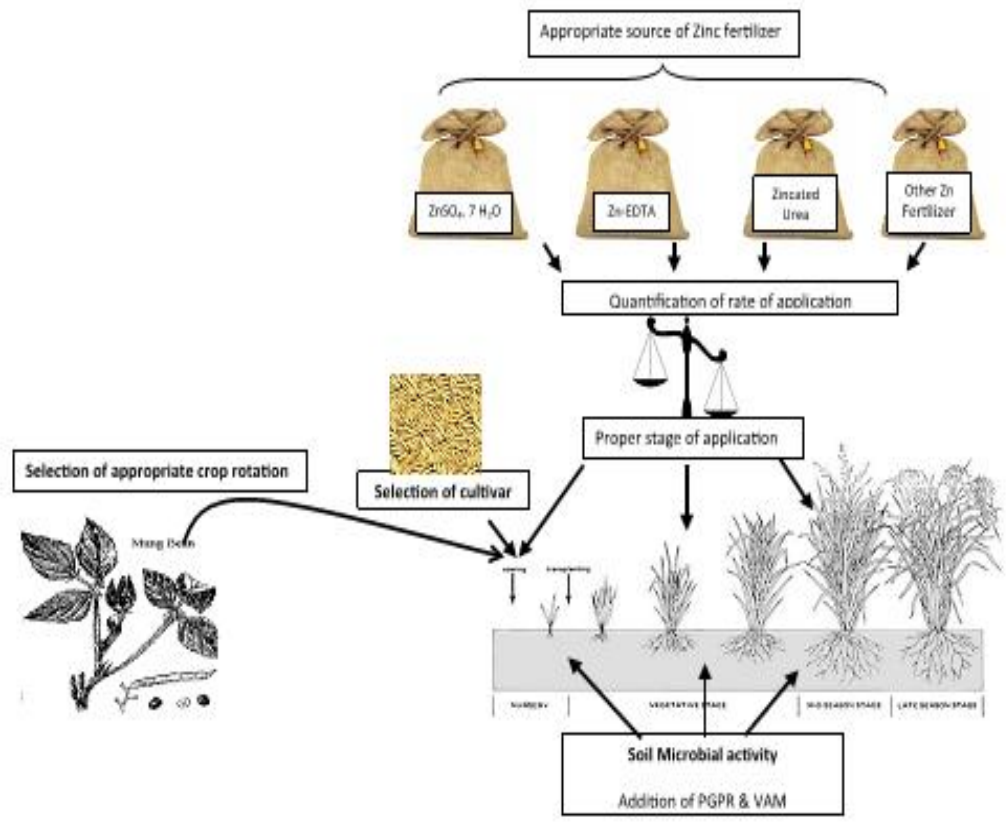


Shivay et al., (2015) studied significant increase in Zn concentration in grain over NPK fertilization was recorded with soil application of ZnSHH or Zn-EDTA, which were at par with two or three applications of $0.2 \%$ solutions of $\mathrm{ZnSHH}$ or Zn-EDTA or one or two applications of $0.5 \%$ solutions of ZnSHH or Zn-EDTA. A single application of $0.2 \%$ of ZSHH or Zn-EDTA was inferior to soil application of $\mathrm{Zn}$ and did not significantly increase $\mathrm{Zn}$ concentration in rice grain. In both the years of study $\mathrm{Zn}$ application either to soil or foliage significantly increased ZnMEI over no fertilizer control (Table 4).

Table: 4. Effect of sources, time and method of zinc application on $\mathrm{Zn}$ concentration in grain of basmati rice.

\begin{tabular}{|c|c|c|c|c|}
\hline \multirow[t]{2}{*}{ Treatment } & \multicolumn{2}{|c|}{$\begin{array}{l}\text { Zn concentration in rice } \\
\text { grain }\left(\mathrm{mg} \mathrm{kg}^{-1}\right)\end{array}$} & \multicolumn{2}{|c|}{$\begin{array}{l}\text { Zn mobilization efficiency } \\
\text { index (ZnMEI) }\end{array}$} \\
\hline & 2010 & 2011 & 2010 & 2011 \\
\hline Absolute control & 20.7 & 21.2 & 0.28 & 0.28 \\
\hline NPK (120 kg N+26.2 kg P+60 kg K) & 23.1 & 23.6 & 0.29 & 0.29 \\
\hline $\mathrm{NPK}+5 \mathrm{~kg} \mathrm{Zn}$ ha $^{-1}$ through $\mathrm{ZnSHH}$ as SA & 26.4 & 26.9 & 0.30 & 0.30 \\
\hline NPK+ ZnSHH $0.2 \%$ FSAT & 24.8 & 25.3 & 0.29 & 0.29 \\
\hline NPK+ ZnSHH $0.2 \%$ FSAT+B stages & 26.3 & 26.8 & 0.30 & 0.30 \\
\hline NPK+ ZnSHH $0.2 \%$ FSAT + B+ GF stages & 26.8 & 27.3 & 0.30 & 0.30 \\
\hline NPK+ ZnSHH $0.5 \%$ FSAT & 25.4 & 25.9 & 0.30 & 0.30 \\
\hline $\mathrm{NPK}+\mathrm{ZnSHH} 0.5 \%$ FSAT +B stages & 26.6 & 27.1 & 0.29 & 0.30 \\
\hline NPK+ ZnSHH $0.5 \%$ FSAT+ B+ GF stages & 28.2 & 28.7 & 0.30 & 0.30 \\
\hline NPK+ 5kgZnha ${ }^{-1}$ through Zn-EDTA as SA & 27.8 & 28.3 & 0.30 & 0.30 \\
\hline NPK+ Zn-EDTA $0.2 \%$ FSAT & 24.7 & 25.2 & 0.29 & 0.29 \\
\hline NPK + Zn-EDTA $0.2 \%$ FSAT+B stages & 26.6 & 27.1 & 0.30 & 0.30 \\
\hline NPK+ Zn-EDTA $0.2 \%$ FSAT+ B+ GF stages & 27.7 & 28.2 & 0.30 & 0.30 \\
\hline NPK+ Zn-EDTA $0.5 \%$ FSAT & 25.8 & 26.3 & 0.29 & 0.29 \\
\hline NPK+ Zn-EDTA $0.5 \%$ FSAT+ B stages & 28.2 & 28.7 & 0.30 & 0.30 \\
\hline NPK + Zn-EDTA $0.5 \%$ FSAT +B +GF stages & 29.8 & 30.3 & 0.31 & 0.31 \\
\hline $\mathrm{CD}(\mathrm{P}=0.05)$ & 2.1 & 1.7 & 0.01 & 0.02 \\
\hline
\end{tabular}

Phattarakul et al., (2012) revealed that $\mathrm{Zn}$ concentration in brown rice was increased by $25 \%$ and $32 \%$ by foliar and foliar + soil Zn applications, respectively, while there was only $2.4 \%$ increase with soil $\mathrm{Zn}$ application. In some locations in India and Thailand, foliar $\mathrm{Zn}$ application increased brown rice $\mathrm{Zn}$ by about $60 \%$ (Table 5). The effectiveness of foliar $\mathrm{Zn}$ application on grain $\mathrm{Zn}$ varied substantially between years for a given genotype, indicating important role of environmental conditions on seed deposition of foliar applied $\mathrm{Zn}$. There were also some genotypes which showed better response to foliar Zn application such as IR68144 as compare to other varieties in Thailand. And also reported that the $\mathrm{Zn}$ concentration of un-husked, brown and white rice were all increased much more markedly by the foliar $\mathrm{Zn}$ applications made at milk stage while only minimal increases in grain $\mathrm{Zn}$ were found when $\mathrm{Zn}$ applications were made at tillering and booting stages (Fig. 5).

Table: 5. Zinc concentration of brown rice grown with different methods of $\mathrm{Zn}$ fertilizer treatments.

\begin{tabular}{|c|c|c|c|c|c|c|c|c|}
\hline \multirow[t]{2}{*}{ Country } & \multirow[t]{2}{*}{ Location } & \multirow{2}{*}{$\begin{array}{l}\mathrm{pH}, \quad \text { OC } \quad(\%) \text { and } \\
\text { DTPA-Zn }\left(\mathrm{mg} \mathrm{kg}^{-1}\right)\end{array}$} & \multirow[t]{2}{*}{ Year } & \multirow[t]{2}{*}{ Variety } & Nil & Soil Zn & Foliar Zn & Soil + foliar Zn \\
\hline & & & & & \multicolumn{4}{|c|}{$\mathrm{Zn}$ in brown rice $\left(\mathrm{mg} \mathrm{Zn} \mathrm{Kg}^{-1}\right)$} \\
\hline \multirow[t]{2}{*}{ China } & Anhui & $4.8,0.3 \& 0.9$ & 2008 & GLY No.6 & $17.6 \mathrm{a}$ & $20.4 \mathrm{~b}$ & $24.3 \mathrm{c}$ & $26.2 \mathrm{c}$ \\
\hline & Zhejiand & $5.6,0.1 \& 4.3$ & 2008 & GLY No.6 & $23.3 \mathrm{a}$ & $23.8 \mathrm{a}$ & $26.6 \mathrm{~b}$ & $27.9 \mathrm{~b}$ \\
\hline \multirow[t]{4}{*}{ India } & Ludhiana & $7.6,0.4 \& 6.5$ & 2009 & PR 120 & $23.6 \mathrm{a}$ & $26.7 \mathrm{a}$ & $28.9 \mathrm{~b}$ & $30.3 b$ \\
\hline & & & 2010 & PR 120 & $16.3 \mathrm{a}$ & $20.3 \mathrm{ab}$ & $23.6 \mathrm{~b}$ & $25.2 \mathrm{~b}$ \\
\hline & Langroya & $8.8,0.3 \& 5.5$ & 2009 & PR 118 & $21.8 \mathrm{a}$ & $25.1 \mathrm{ab}$ & $27.0 \mathrm{~b}$ & $30.0 \mathrm{~b}$ \\
\hline & Kapurthala & $7.6,0.3 \& 2.2$ & 2010 & PR 118 & $18.1 \mathrm{a}$ & $23.0 \mathrm{~b}$ & $29.0 \mathrm{c}$ & $24.9 \mathrm{~b}$ \\
\hline \multirow[t]{3}{*}{ Thailand } & Chiang Mai & $6.2,0.9, \& 2.1$ & 2008 & CNT 1 & $20.6 \mathrm{a}$ & $20.6 \mathrm{a}$ & $25.8 \mathrm{~b}$ & $26.6 \mathrm{~b}$ \\
\hline & & & 2009 & CNT 1 & $19.6 \mathrm{a}$ & $20.4 \mathrm{a}$ & $22.5 \mathrm{~b}$ & $24.3 \mathrm{c}$ \\
\hline & & & 2009 & IR 68144 & $31.0 \mathrm{a}$ & $31.5 \mathrm{a}$ & $32.1 \mathrm{a}$ & $35.7 \mathrm{a}$ \\
\hline Mean & & & & & 19.4 & 20.8 & 24.2 & 25.5 \\
\hline \multicolumn{5}{|c|}{$\%$ increase in brown rice $\mathrm{Zn}$ over nil } & & 2.4 & 24.7 & 31.9 \\
\hline
\end{tabular}


Fig: 5. Zn concentration in un-husked, brown and white rice as affected by methods of foliar Zn application at different stages.

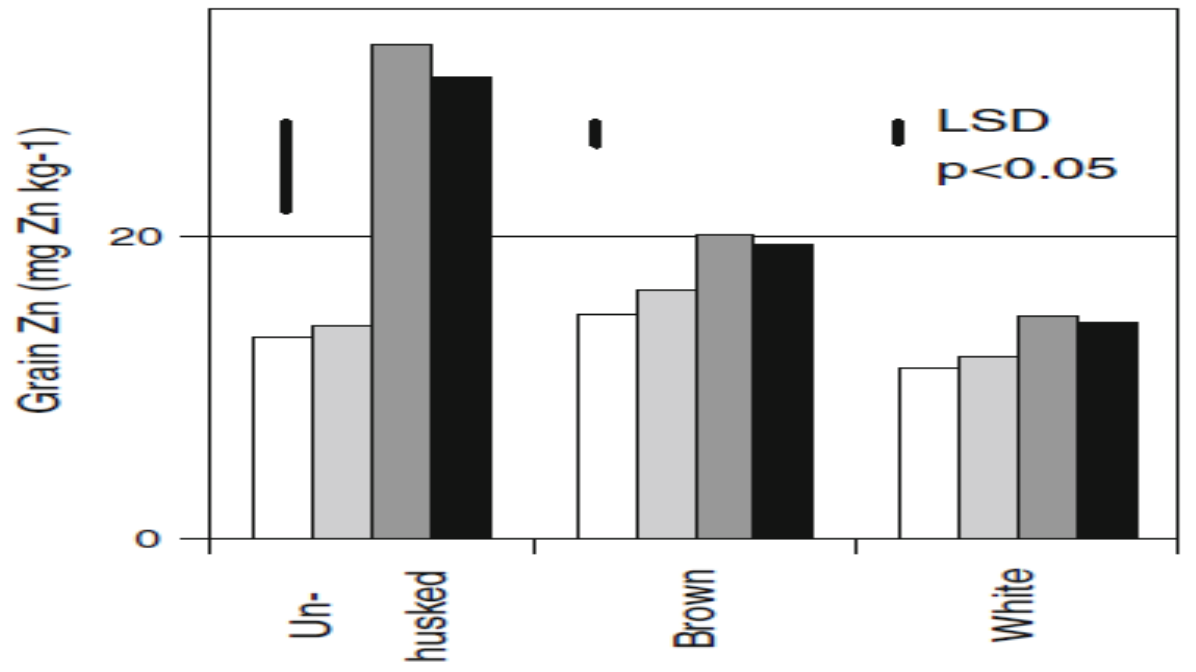

Prasad et al., (2014) showed that application of $\mathrm{Zn}$ as $2 \%$ zinc sulfate heptahydrate with coated urea, $\left(5.2 \mathrm{~kg} \mathrm{Zn}^{-}\right.$ ${ }^{1}$ ) as soil applied significantly increased grain yield of rice as well as $\mathrm{Zn}$ concentration in rice grain and application of $\mathrm{Zn}$ as $0.5 \% \mathrm{ZnSo}_{4} 7 \mathrm{H}_{2} \mathrm{O}\left(1.2 \mathrm{~kg} \mathrm{Zn} \mathrm{ha}^{-1}\right)$ as foliar application in case of biofortification recovery efficiency significantly better than other treatments (Table 6).

Table: 6. Effect of method, source and rate of $\mathrm{Zn}$ application on grain yield, $\mathrm{Zn}$ content and bio-fortification recovery efficiency of basmati rice.

\begin{tabular}{|c|c|c|c|c|}
\hline Treatment & $\begin{array}{l}\text { Grain yield } \\
\left(\mathrm{t} \mathrm{ha}^{-1}\right)\end{array}$ & $\begin{array}{l}\mathrm{Zn} \text { concentration in } \\
\text { unhusked rice ( } \mathrm{mg} \\
\left.\mathrm{kg}^{-1}\right)\end{array}$ & $\begin{array}{l}\mathrm{Zn} \text { concentration } \\
\text { in polished rice } \\
\left(\mathrm{mg} \mathrm{kg}^{-1}\right)\end{array}$ & $\begin{array}{l}\mathrm{BRE}_{\mathrm{Zn}} \\
(\%)\end{array}$ \\
\hline No Zn & 3.92 & 30.4 & 26.1 & - \\
\hline $\begin{array}{l}25 \mathrm{~kg} \mathrm{ZnSO} \mathrm{Zn}_{4} \cdot 7 \mathrm{H}_{2} \mathrm{O} \mathrm{ha}^{-1}(5.3 \mathrm{~kg} \mathrm{Zn} \\
\left.\mathrm{ha}^{-1}\right) \text { Soil application }\end{array}$ & 5.20 & 47.5 & 40.3 & 1.42 \\
\hline $0.2 \% \mathrm{ZnSO}_{4} .7 \mathrm{H}_{2} \mathrm{O}$ foliar application $\left(1.2 \mathrm{~kg} \mathrm{Zn} \mathrm{ha}^{-1}\right)$ & 4.99 & 52.6 & 28.8 & 2.42 \\
\hline $\begin{array}{l}\text { Soil application of } 1 \% \mathrm{ZnO} \text {-coated urea }(2.6 \mathrm{~kg} \mathrm{Zn} \\
\left.\mathrm{ha}^{-1}\right)\end{array}$ & 4.48 & 38.2 & 32.4 & 1.16 \\
\hline Soil application of $2 \% \mathrm{ZnO}$-coated urea $\left(5.2 \mathrm{~kg} \mathrm{Zn} \mathrm{ha}^{-1}\right)$ & 5.13 & 44.7 & 37.9 & 1.24 \\
\hline $\begin{array}{l}\text { Soil application of } 1 \% \mathrm{ZnSO}_{4} .7 \mathrm{H}_{2} \mathrm{O} \text { coated urea }(2.6 \mathrm{~kg} \\
\left.\mathrm{Zn} \mathrm{ha}^{-1}\right)\end{array}$ & 4.69 & 40.3 & 34.1 & 1.55 \\
\hline $\begin{array}{l}\text { Soil application of } 2 \% \mathrm{ZnSO}_{4} \cdot 7 \mathrm{H}_{2} \mathrm{O} \text { coated urea }(5.2 \mathrm{~kg} \\
\left.\mathrm{Zn} \mathrm{ha}^{-1}\right)\end{array}$ & 5.27 & 49.7 & 42.1 & 1.61 \\
\hline $\mathrm{CD}(\mathrm{P}=0.05)$ & 0.45 & 4.5 & - & - \\
\hline
\end{tabular}

Purakayastha and Chhonkar (2001) examined that influence of the VAMF, Glomus etunicatum, was significant in enhancing grain yields of rice as compared to the un-inoculated control. The inoculation increased the content and uptake of $\mathrm{Zn}$ by rice (Table 7) and the highest content of $\mathrm{Zn}$ were observed in the NPK+ZnSO4 as compare to other treatment.

Table: 7. Grain yield and $\mathrm{Zn}$ content of rice without and with inoculation of roots with Glomus etunicatum.

\begin{tabular}{|l|c|c|c|c|c|c|}
\hline & \multicolumn{2}{|l|}{ Grain yield $\left(\mathrm{g} \mathrm{pot}^{-1}\right)$} & \multicolumn{2}{c|}{ Content of Zn $\left(\mu \mathrm{g} \mathrm{g}^{-1}\right)$} \\
\hline Fertilization & $\mathrm{U}$ & $\mathrm{I}$ & Mean & $\mathrm{U}$ & $\mathrm{I}$ & Mean \\
\hline NPK & 24.2 & 28.4 & 26.3 & 14.2 & 18.7 & 16.4 \\
\hline NPK+ZnSO4 & 27.0 & 29.8 & 28.4 & 18.1 & 21.8 & 19.9 \\
\hline NPK+FYM & 23.2 & 24.4 & 23.8 & 14.6 & 20.9 & 17.7 \\
\hline NPK+ZnSO4+FYM & 24.1 & 25.3 & 24.7 & 14.5 & 17.8 & 16.1 \\
\hline Mean & 24.6 & 27.0 & & 15.3 & 19.8 & \\
\hline CD $(\mathrm{P}=0.05)$ & 1.8 & 1.6 & 2.1 & 1.7 & 1.5 & 2.3 \\
\hline
\end{tabular}


Prasad et al., (2013) Zn enrichment of urea @ 2\% Zn as zinc sulphate increased the grain Zn concentration by $61.8 \%$ in rice and by $51.1 \%$ in wheat (Fig 6).

Fig: 6. Grain $\mathrm{Zn}$ concentration in rice due to degree of $\mathrm{Zn}$ enrichment of urea.

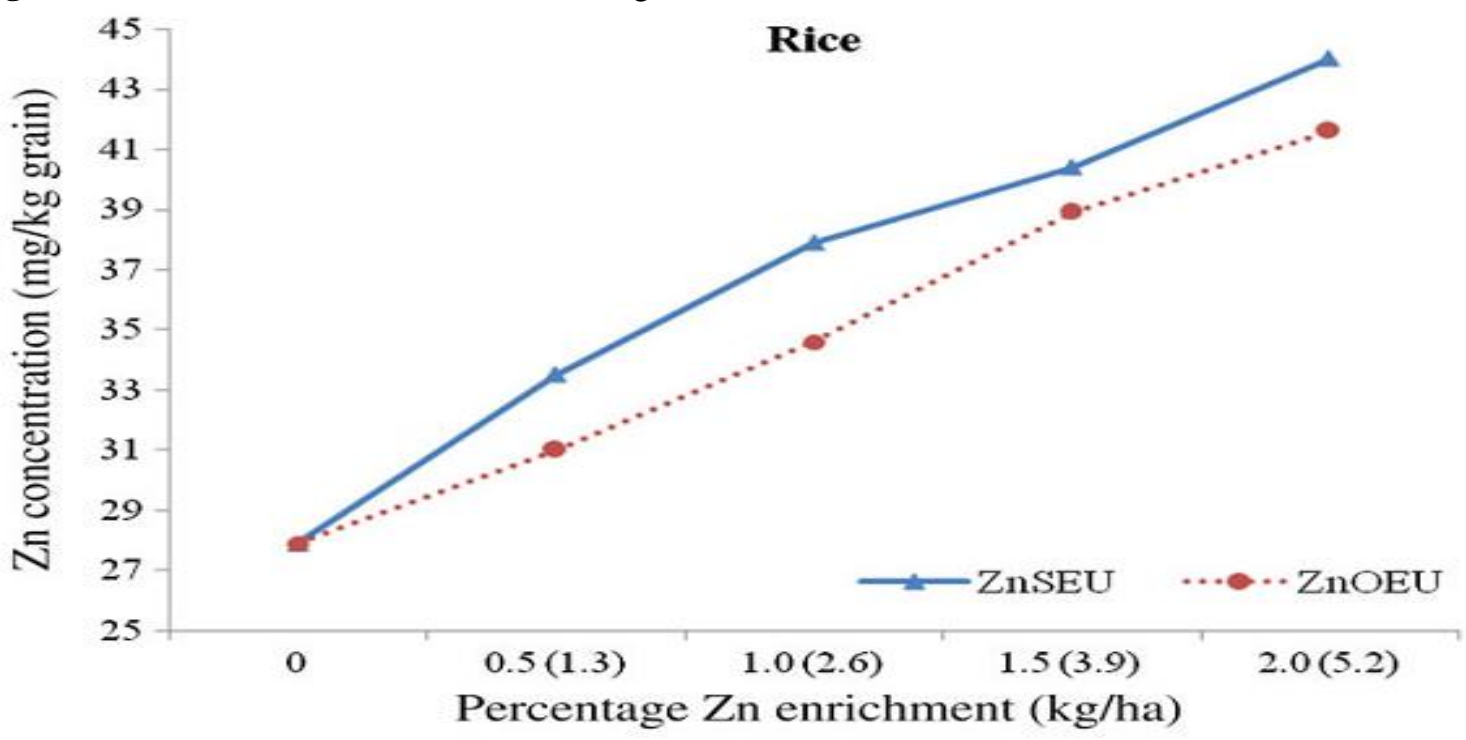

Hari Ram et al., (2015) studied that soil Zn application increased wheat grain yield up to $50 \%$ and rice grain yield only up to $14.8 \%$. Soils rich in $\mathrm{Zn}$ showed no or little effect on grain yield when $\mathrm{Zn}$ was applied. The spraying of 3.0 $\mathrm{kg} \mathrm{ZnSO} 4.7 \mathrm{H}_{2} \mathrm{O}$ in two applications at the flowering and early grain development stages increased the grain zinc significantly irrespective of the soil types. Application of foliar $\mathrm{Zn}$ with or without propiconazole resulted in significant increase in grain $\mathrm{Zn}$, which was $38-40 \%$ in rice and $87-150 \%$ in wheat, over no $\mathrm{Zn}$ (Fig 7).

Fig: 7. Effect of various zinc fertilizer treatments on the grain yield of rice and wheat.

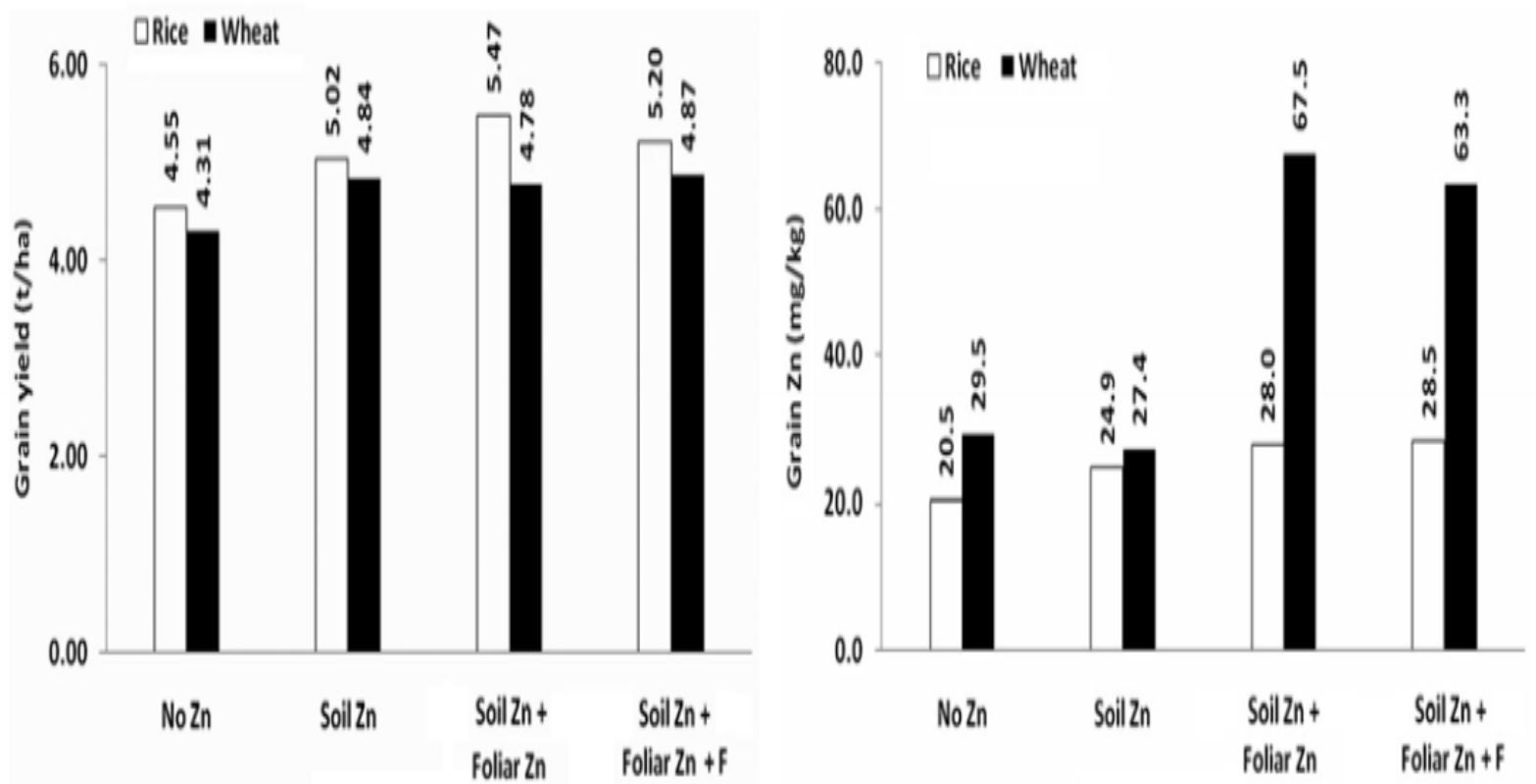

Zou et al., (2012) reported that 83.5 and $89.7 \%$ increases in grain $\mathrm{Zn}$ concentration by foliar $\mathrm{Zn}$ alone and soil + foliar $\mathrm{Zn}$ application, respectively while soil $\mathrm{Zn}$ application was less effective (Table 8). The increments in grain $\mathrm{Zn}$ associated with only foliar $\mathrm{Zn}$ spray was more than $10 \mathrm{mg} \mathrm{Zn} \mathrm{kg}^{-1}$ grain. In the case of soil + foliar Zn application, an increment of $20 \mathrm{mg} \mathrm{kg}^{-1}$ grain was found in half of the field tests. 
Table: 8.Grain $\mathrm{Zn}$ concentration of wheat grown with $\mathrm{Zn}$ fertilizer treatments.

\begin{tabular}{|c|c|c|c|c|c|c|c|c|}
\hline \multirow[t]{2}{*}{ Country } & \multirow[t]{2}{*}{ Location } & \multirow{2}{*}{$\begin{array}{l}\text { pH and DTPA-Zn } \\
\left(\mathrm{mg} \mathrm{kg}^{-1}\right)\end{array}$} & \multirow[t]{2}{*}{ Year } & \multicolumn{4}{|c|}{ Grain $\mathrm{Zn}$ concentration $\left(\mathrm{mg} \mathrm{kg}^{-1}\right)$} & \multirow{2}{*}{$\begin{array}{c}\mathrm{CD} \\
(\mathrm{P}=0.05)\end{array}$} \\
\hline & & & & Nil & Soil Zn & Foliar Zn & Soil + foliar Zn & \\
\hline \multirow[t]{4}{*}{ China } & Quzhou & $7.8 \& 0.32$ & 2009 & 27.7 & 32.4 & 47.2 & 53.9 & 3.5 \\
\hline & & & 2010 & 29.5 & 40.9 & 44.3 & 52.0 & 6.8 \\
\hline & Yongshou & $8.0 \& 0.31$ & 2009 & 18.8 & 21.0 & 26.5 & 22.5 & 3.8 \\
\hline & & & 2010 & 19.5 & 22.1 & 31.4 & 34.0 & 3.5 \\
\hline \multirow[t]{5}{*}{ India } & Varanasi & $7.7 \& 0.86$ & 2008 & 29.0 & 32.0 & 44.0 & 47.0 & 12.0 \\
\hline & Kapurthala & $7.6 \& 2.2$ & 2010 & 49.0 & 52.0 & 64.8 & 65.3 & 7.4 \\
\hline & & & 2011 & 31.4 & 30.2 & 51.1 & 49.1 & 7.9 \\
\hline & Ludhiana & $7.6 \& 6.5$ & 2010 & 25.5 & 30.3 & 61.0 & 60.8 & 7.5 \\
\hline & & & 2011 & 27.3 & 36.7 & 58.3 & 57.0 & 6.4 \\
\hline Pakistan & Faisalabad & $-\& 1.3$ & 2008 & 29.0 & 29.0 & 60.0 & 59.0 & 9.0 \\
\hline \multicolumn{3}{|l|}{ Mean } & & 27.4 & 30.5 & 48.0 & 49.0 & \\
\hline \multicolumn{3}{|c|}{$\%$ increase over nil } & & & 12.3 & 83.5 & 89.7 & \\
\hline
\end{tabular}

Mohsin et al., (2014) Maximum grain yield (Table 9) were recorded in maize hybrid Pioneer 30 -Y-87 with combined application of $\mathrm{Zn}$ as seed priming (2\%) and foliar spray (2\%) during both the years. Improvement in grain yield was $20 \%$ and $22 \%$, during the year 2009 and 2010, respectively. Seed priming with $\mathrm{Zn}$ solution. Different $\mathrm{Zn}$ application methods improved kernel $\mathrm{Zn}$ contents, however, combined application of $\mathrm{Zn}$ as seed priming (2\%) and foliage spray (2\%) in maize hybrid DK-919 gave $43.61 \%$ and $36.56 \%$ more grain $\mathrm{Zn}$ content, respectively during the year 2009 and 2010 than any other.

Table: 9. Influence of zinc application through seed treatment and foliar spray on grain yield and grain $\mathrm{Zn}$ content of maize.

\begin{tabular}{|c|c|c|c|c|}
\hline Treatment & \multicolumn{2}{|c|}{ Grain yield $\left(\mathrm{t} \mathrm{ha}^{-1}\right)$} & \multicolumn{2}{c|}{ Grain Zn content $\left(\mathrm{mg} \mathrm{kg}^{-1}\right)$} \\
\hline & 2009 & 2010 & 2009 & 2010 \\
\hline $\mathrm{CK}$ & $5.80 \mathrm{~g}$ & $5.52 \mathrm{~g}$ & $19.88 \mathrm{~g}$ & $21.44 \mathrm{~g}$ \\
\hline $\mathrm{SP}_{1}$ & $6.09 \mathrm{f}$ & $5.83 \mathrm{f}$ & $22.52 \mathrm{f}$ & $23.52 \mathrm{f}$ \\
\hline $\mathrm{SP}_{2}$ & $6.14 \mathrm{f}$ & $5.85 \mathrm{ef}$ & $22.57 \mathrm{f}$ & $23.66 \mathrm{f}$ \\
\hline $\mathrm{F}_{1}$ & $6.24 \mathrm{ef}$ & $5.94 \mathrm{e}$ & $23.11 \mathrm{e}$ & $24.10 \mathrm{e}$ \\
\hline $\mathrm{F}_{2}$ & $6.60 \mathrm{~cd}$ & $6.35 \mathrm{c}$ & $27.04 \mathrm{~b}$ & $27.74 \mathrm{~b}$ \\
\hline $\mathrm{SP}_{1}+\mathrm{F}_{1}$ & $6.41 \mathrm{de}$ & $6.14 \mathrm{~d}$ & $23.98 \mathrm{~d}$ & $25.15 \mathrm{~d}$ \\
\hline $\mathrm{SP}_{1}+\mathrm{F}_{2}$ & $6.81 \mathrm{ab}$ & $6.56 \mathrm{~b}$ & $27.06 \mathrm{~b}$ & $27.79 \mathrm{~b}$ \\
\hline $\mathrm{SP}_{2}+\mathrm{F}_{1}$ & $6.66 \mathrm{bc}$ & $6.35 \mathrm{c}$ & $25.55 \mathrm{c}$ & $26.89 \mathrm{c}$ \\
\hline $\mathrm{SP}_{2}+\mathrm{F}_{2}$ & $6.96 \mathrm{a}$ & $6.73 \mathrm{a}$ & $28.55 \mathrm{a}$ & $29.28 \mathrm{a}$ \\
\hline
\end{tabular}

Shivay and Prasad (2014) In both the years of study One to three foliar applications of 0.2 or $0.5 \%$ solutions of $\mathrm{ZSHH}$ or one to three foliar applications of $0.2 \%$ solution of Zn-EDTA or a single application of $0.5 \%$ solution of $\mathrm{Zn}$-EDTA were equally effective and at par with soil application of ZnSHH or Zn-EDTA. In both the years of study two or three foliar applications of $0.5 \%$ solution of $\mathrm{Zn}$ - EDTA produced the highest yield and yield attributes of Basmati rice, significantly more than soil application of $\mathrm{ZnSHH}$ or $\mathrm{Zn}$-EDTA and most other treatments of foliar spray. (Table 10).

Table: 10. Effect of source and method of $\mathrm{Zn}$ application on yield attributes and yield of maize.

\begin{tabular}{|l|c|c|c|c|c|}
\hline Treatment $\left(\mathrm{Zn} \mathrm{ha}^{-1}\right)$ & $\begin{array}{c}\text { Cob length } \\
(\mathrm{cm})\end{array}$ & $\begin{array}{c}\text { Grain weight } \\
\left(\mathrm{g} \mathrm{cob}-{ }^{1}\right)\end{array}$ & $\begin{array}{c}1,000 \text {-grain wt } \\
(\mathrm{g})\end{array}$ & $\begin{array}{c}\text { Grain yield } \\
\left(\mathrm{t} \mathrm{ha}^{-1}\right)\end{array}$ & $\begin{array}{c}\text { Stover yield } \\
\left(\mathrm{t} \mathrm{ha}^{-1}\right)\end{array}$ \\
\hline Control & 13.0 & 70.6 & 190.0 & 4.00 & 6.10 \\
\hline $5 \mathrm{~kg}$ to soil & 14.0 & 74.9 & 199.3 & 4.70 \\
\hline $1 \mathrm{~kg}$ foliar & 13.5 & 72.8 & 193.3 & 4.42 & 6.68 \\
\hline $5 \mathrm{~kg}$ to soil $+1 \mathrm{~kg}$ foliar & 15.2 & 76.5 & 201.5 & 5.10 & 7.50 \\
\hline $2.83 \mathrm{~kg}$ through Zn-coated urea (to soil) & 14.4 & 75.2 & 200.5 & 4.80 \\
\hline CD $(\mathrm{P}=0.05)$ & 2.1 & 4.1 & $\mathrm{NS}$ & 0.38 & 6.90 \\
\hline
\end{tabular}


Shivay and Prasad (2014) found that significant increase in Zn concentration in grain and straw over NPK fertilization was recorded with soil application of $\mathrm{ZnSHH}$ or $\mathrm{Zn}-\mathrm{EDTA}$, which were at par with two or three applications of $0.2 \%$ solutions of $\mathrm{ZnSHH}$ or $\mathrm{Zn}-\mathrm{EDTA}$ or one or two applications of $0.5 \%$ solutions of $\mathrm{ZnSHH}$ or $\mathrm{Zn}$-EDTA. A single application of $0.2 \%$ of ZSHH or Zn-EDTA was inferior to soil application of Zn and did not significantly increase $\mathrm{Zn}$ concentration in rice grain and straw. The highest $\mathrm{Zn}$ concentration in grains and straw of Basmati was recorded with three foliar applications of $0.5 \%$ solution of $\mathrm{Zn}$-EDTA, significantly more than soil application of $\mathrm{ZnSHH}$ or $\mathrm{Zn}$-EDTA and most other foliar application treatments (Table 11).

Table: 11. Effect of source and method of $\mathrm{Zn}$ application on $\mathrm{Zn}$ concentration in grain and stover and mobilization efficiency index in maize.

\begin{tabular}{|l|c|c|c|}
\hline Treatment $\left(\mathrm{Zn} \mathrm{ha}^{-1}\right)$ & $\begin{array}{c}\text { Grain Zn concentration } \\
\left(\mathrm{mg} \mathrm{kg}^{-1} \text { grain }\right)\end{array}$ & $\begin{array}{c}\text { Stover Zn concentration } \\
\left(\mathrm{mg} \mathrm{kg}^{-1} \mathrm{DM}\right)\end{array}$ & $\begin{array}{c}\text { Zn Mobilization } \\
\text { efficiency index }\end{array}$ \\
\hline Control & 40.2 & 45.0 & 0.89 \\
\hline $5 \mathrm{~kg}$ to soil & 44.2 & 49.2 & 0.90 \\
\hline $1 \mathrm{~kg}$ foliar & 46.0 & 59.2 & 0.78 \\
\hline $5 \mathrm{~kg}$ to soil $+1 \mathrm{~kg}$ foliar & 49.2 & 64.5 & 0.76 \\
\hline $2.83 \mathrm{~kg}$ through Zn-coated urea (to soil) & 45.8 & 58.2 & 0.79 \\
\hline CD $(\mathrm{P}=0.05)$ & 2.0 & 2.7 & 0.03 \\
\hline
\end{tabular}

Kanwal et al., (2010) studied that Zinc application to soil had a significant $(\mathrm{p}<0.05)$ effect on grain yield of both the maize hybrid FHY-421 and synthetic variety Golden (Fig. 8). Cultivars also differed significantly $(\mathrm{p}<0.01)$ for the grain yield. Maximum increase $(21 \%)$ in grain yield of hybrid (FHY-421) was observed when the Zn was applied @ $18 \mathrm{~kg} \mathrm{ha}^{-1}$, while synthetic variety (Golden) exhibited maximum increase (13\%) in grain yield when Zn was applied @ $6 \mathrm{~kg} \mathrm{ha}^{-1}$ to the soil.

Fig: 8. Grain yield of maize at different rates of $\mathrm{Zn}$ application.

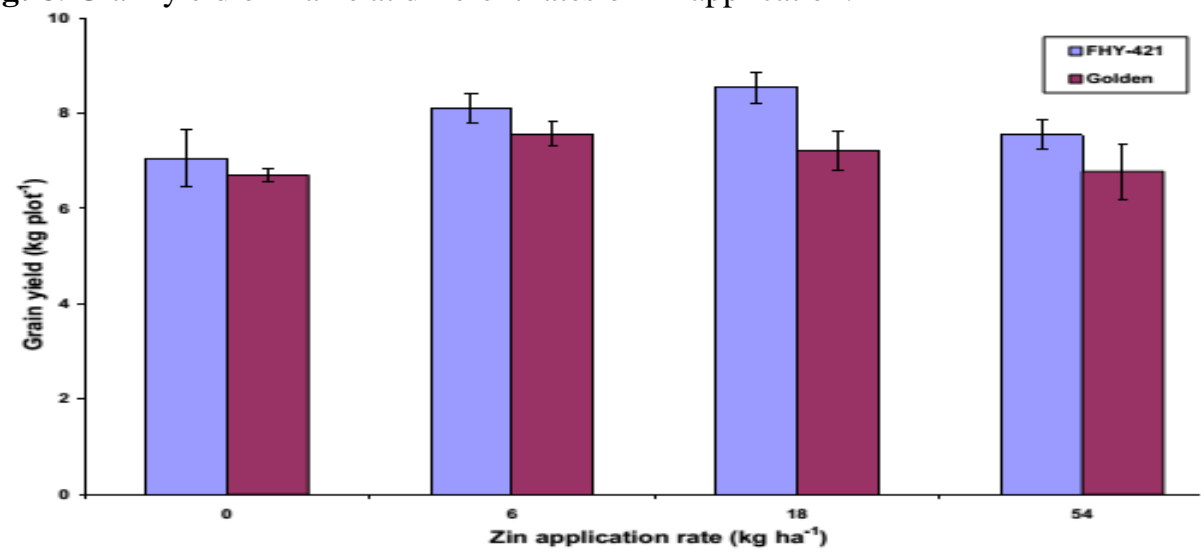

Effect of iron deficiency:-

Shing et al., (2013) Three foliar sprays of FeSO4.7H2O @ 0.5 and 1\% levels at different growth stages of rice crop significantly increased the yield of rice cultivars (Table 12). The data showed that the maximum grain yield was reported in PAU 201 cultivar $\left(82.8 \mathrm{q} \mathrm{ha}^{-1}\right)$ and minimum grain yield was reported in PR120 cultivar $\left(78.7 \mathrm{q} \mathrm{ha}{ }^{-1}\right)$ with 0.5 percent level of FeSO4.7H2O spray. The grain yield of PR113, PR116 and PR118 cultivars with 0.5 per cent level of FeSO4.7H2O spray ranged from 79.0- 80.1 $\mathrm{q} \mathrm{ha}^{-1}$. With three foliar sprays of FeSO4.7H2O with 0.5 per cent level at different growth stages of rice crop, the grain yield of PR113, PR116, PR118, PR120 and PAU 201 cultivars increased by 5.1, 4.3, 2.9, 3.2 and 3.8 per cent respectively, over control.

Table: 12. Grain yield $\left(\mathrm{q} \mathrm{ha}^{-1}\right)$ of different rice cultivars as affected by foliar spray of $\mathrm{FeSO}_{4} .7 \mathrm{H}_{2} \mathrm{O}$.

\begin{tabular}{|c|c|c|c|c|c|}
\hline \multirow[t]{2}{*}{ Treatment } & \multicolumn{5}{|c|}{ Rice cultivars } \\
\hline & PR 113 & PR 116 & PR 118 & PR 120 & PAU 201 \\
\hline Control & 75.3 & 75.7 & 77.8 & 76.2 & 79.7 \\
\hline $0.5 \% \mathrm{FeSO}_{4}$ & 79.2 & 79.0 & 80.1 & 78.7 & 82.8 \\
\hline$\%$ increase over control & 5.1 & 4.3 & 2.9 & 3.2 & 3.8 \\
\hline $1 \% \mathrm{FeSO}_{4}$ & 81.2 & 80.4 & 80.7 & 79.5 & 84.0 \\
\hline$\%$ increase over control & 7.8 & 6.2 & 3.7 & 4.3 & 5.3 \\
\hline $\mathrm{CD}(\mathrm{P}=0.05)$ & 0.2 & 2.2 & 0.1 & 0.1 & 0.2 \\
\hline
\end{tabular}


Shing et al., (2013) The data showed that three foliar sprays of FeSO4.7H2O with 0.5 per cent and 1 per cent levels at different growth stages of rice crop (maximum tillering, pre-anthesis and post-anthesis stages) significantly increased $\mathrm{Fe}$ concentration in brown rice of different rice cultivars as compared to control but results shown by PR113 cultivar were non- significant (Table 13).

Table: 13. Effect of foliar spray of $\mathrm{FeSO}_{4} \cdot 7 \mathrm{H}_{2} \mathrm{O}$ on $\mathrm{Fe}$ concentration in brown rice of different rice cultivars.

\begin{tabular}{|l|c|c|c|c|c|}
\hline \multirow{2}{*}{ Treatment } & \multicolumn{5}{|c|}{ Rice cultivars } \\
\cline { 2 - 6 } & PR 113 & PR 116 & PR 118 & PR 120 & PAU 201 \\
\hline & \multicolumn{5}{|c|}{ Fe concentration in brown rice $\left(\mathrm{mg} \mathrm{kg}^{-1}\right)$} \\
\hline Control & 15.2 & 14.8 & 13.0 & 17.8 & 12.5 \\
\hline $0.5 \% \mathrm{FeSO}_{4}$ & 18.8 & 20.5 & 19.7 & 20.2 & 19.8 \\
\hline$\%$ increase over control & 23.6 & 38.5 & 51.5 & 13.4 & 58.4 \\
\hline $1 \% \mathrm{FeSO}_{4}$ & 26.4 & 25.8 & 26.5 & 28.2 & 28.8 \\
\hline$\%$ increase over control & 73.6 & 74.3 & 103.8 & 58.4 & 130.4 \\
\hline $\mathrm{CD}(\mathrm{P}=0.05)$ & $\mathrm{NS}$ & 3.1 & 1.1 & 6.2 & 5.7 \\
\hline
\end{tabular}

Aciksoz et al., (2011) examined that application of urea alone and with iron fertilizer found non-significant grain yield over all treatment. And highest iron concentration in grain with the application of FeSO4 + Urea and at par with FeEDTA + Urea and Fe EDDHA + Urea as compare to over treatments (Table 14).

Table: 14. Effect of Fe with urea in grain yield and Fe concentrations in grain.

\begin{tabular}{|l|c|c|}
\hline Foliar applications & Grain Yield $\left(\mathrm{g} \mathrm{plant}^{-1}\right)$ & Fe concentration in Grain $\left(\mathrm{mg} \mathrm{kg}^{-1}\right)$ \\
\hline Control & 2.71 & 36 \\
\hline Control + Urea & 3.34 & 36 \\
\hline FeSO4 & 2.73 & 38 \\
\hline FeSO4+ Urea & 2.69 & 43 \\
\hline FeEDTA & 3.07 & 38 \\
\hline FeEDTA + Urea & 3.38 & 42 \\
\hline FeEDDHA & 3.11 & 35 \\
\hline FeEDDHA + Urea & 2.61 & 39 \\
\hline Fe Citrate & 2.54 & 36 \\
\hline Fe Citrate + Urea & 2.97 & 37 \\
\hline CD $(\mathrm{P}=0.05)$ & N.S. & 5 \\
\hline
\end{tabular}

\section{Effect of both the zinc and iron deficiency:-}

Dhaliwal et al., (2014) revealed that foliar application of $\mathrm{Zn}$ raised the maximum grain yield up to $49.58 \mathrm{q} \mathrm{ha}^{-1}$ (PBW 550) and $47.82 \mathrm{q} \mathrm{ha}^{-1}$ (PBW 17), which were 9.22 and 6.30 per cent higher than control, respectively. The yield of wheat with foliar application of $\mathrm{Zn}$ varied from 5.11 to $9.68 \%$ in different cultivars. Similarly, the application of Fe increased the grain yield up to $49.35 \mathrm{q} \mathrm{ha}^{-1}$ (PBW 550) and $48.52 \mathrm{q} \mathrm{ha}^{-1}$ (PBW 17), which were 8.69 and 7.87 per cent higher than control, respectively (Table 15). And also showed that application of foliar sprays enhanced the content of $\mathrm{Zn}$ and Fe in wheat grains (Table 16) in all the varieties to varying degree of magnitude depending on the cultivars. The average concentration of $\mathrm{Zn}$ in wheat grains was $21.91 \mu \mathrm{g} \mathrm{g}^{-1}$ (range 20.35-23.89 $\mu \mathrm{g}$ $\mathrm{g}^{-1}$ ) in control treatments which increased to $24.74 \mu \mathrm{g} \mathrm{g} \mathrm{g}^{-1}$ (range 21.60-26.39 $\mu \mathrm{g} \mathrm{g}^{-1}$ dry weight) with foliar application of zinc. With foliar application of iron and the per cent increase in Fe content in grains ranged from as low as $9.27 \%$ in PDW-291 and high as $28.00 \%$ in PBW-343. Wide variation in percent increase in Fe concentration with foliar application was observed as it ranged from as low as 9.27\% in variety PDW 291 to as high as 28.00 in variety PBW343. 
Table: 15. Effects of foliar applications of $\mathrm{Zn}$ and $\mathrm{Fe}$ on grain yields $\left(\mathrm{q} \mathrm{ha}^{-1}\right)$ in different wheat cultivars.

\begin{tabular}{|l|c|c|c|c|c|c|c|c|}
\hline Treatment & PBW 343 & PBW 550 & PBW 17 & PDW 233 & PDW 274 & PDW 291 & Average \\
\hline & \multicolumn{7}{|c|}{ Grain yield (q ha $\left.{ }^{-1}\right)$ with foliar Zn } \\
\hline$-\mathrm{Zn}$ & 43.37 & 45.42 & 44.98 & 43.32 & 42.25 & 41.00 & 43.39 \\
\hline$+\mathrm{Zn}(\mathrm{F})$ & 47.57 & 49.58 & 47.82 & 45.92 & 44.40 & 43.30 & 46.43 \\
\hline \% increase & 9.68 & 9.22 & 6.30 & 6.04 & 5.11 & 5.62 & 7.00 \\
\hline & 43.37 & 45.42 & 44.98 & 43.32 & 42.25 & 41.00 & 43.39 \\
\hline -Fe & 46.43 & 49.35 & 48.52 & 46.25 & 43.40 & 42.12 & 46.01 \\
\hline+ Fe (F) & 7.10 & 8.69 & 7.87 & 6.76 & 2.71 & 2.76 & 5.98 \\
\hline \% increase & \multicolumn{7}{|c|}{ Grain yield (q ha ${ }^{-1}$ ) with foliar Fe } \\
\hline
\end{tabular}

Table: 16. Effect of $\mathrm{Zn}$ and Fe sprays on their respective concentration in grains of different wheat cultivars

\begin{tabular}{|l|c|c|c|c|c|c|c|}
\hline Treatment & PBW 343 & PBW 550 & PBW 17 & PDW 233 & PDW 274 & PDW 291 & Average \\
\hline & \multicolumn{7}{|c|}{ Concentration of Zn $\left(\mathrm{mg} \mathrm{kg}^{-1}\right)$ in wheat grains with foliar Zn } \\
\hline$-\mathrm{Zn}$ & 21.42 & 20.56 & 21.38 & 20.35 & 23.89 & 23.36 & 21.91 \\
\hline$+\mathrm{Zn}(\mathrm{F})$ & 24.18 & 26.14 & 26.39 & 21.60 & 25.56 & 24.56 & 24.74 \\
\hline$\%$ increase & 12.62 & 27.15 & 20.81 & 6.16 & 7.07 & 5.15 & 13.16 \\
\hline & \multicolumn{7}{|c|}{ Concentration of Fe $\left(\mathrm{mg} \mathrm{kg}^{-1}\right)$ in wheat grains with foliar Fe } \\
\hline -Fe & 37.42 & 39.14 & 40.47 & 38.90 & 39.14 & 41.99 & 39.51 \\
\hline$+\mathrm{Fe}(\mathrm{F})$ & 47.70 & 45.27 & 48.90 & 44.27 & 46.65 & 45.89 & 46.45 \\
\hline$\%$ increase & 28.00 & 15.66 & 20.99 & 13.76 & 19.17 & 9.27 & 17.81 \\
\hline
\end{tabular}

Table: 17. Effect of nitrogen levels on $\mathrm{Zn}$ and Fe content in grain, stover and harvest index of $\mathrm{Zn}$ and Fe in maize.

\begin{tabular}{|l|c|c|c|c|}
\hline \multirow{2}{*}{ Parameters } & \multicolumn{3}{|c|}{ N levels } \\
\cline { 2 - 5 } & $\mathrm{N}-0$ & N-low & N-opt & N-over \\
\hline GZnC $\left(\mathrm{mg} \mathrm{kg}^{-1}\right)$ & $15.2 \mathrm{~b}$ & $15.2 \mathrm{~b}$ & $16.6 \mathrm{ab}$ & $17.3 \mathrm{a}$ \\
\hline SZnC $\left(\mathrm{mg} \mathrm{kg}^{-1}\right)$ & $18.2 \mathrm{ab}$ & $17.6 \mathrm{~b}$ & $20.9 \mathrm{ab}$ & $21.8 \mathrm{a}$ \\
\hline ZnHI $(\%)$ & $48 \mathrm{a}$ & $49 \mathrm{a}$ & $49 \mathrm{a}$ & $48 \mathrm{a}$ \\
\hline GFeC $\left(\mathrm{mg} \mathrm{kg}^{-1}\right)$ & $13.4 \mathrm{c}$ & $15.5 \mathrm{~b}$ & $16.0 \mathrm{ab}$ & $17.2 \mathrm{a}$ \\
\hline SFeC $\left(\mathrm{mg} \mathrm{kg}^{-1}\right)$ & $63.3 \mathrm{a}$ & $69.6 \mathrm{a}$ & $58.3 \mathrm{a}$ & $60.6 \mathrm{a}$ \\
\hline FeHI $(\%)$ & $19 \mathrm{~b}$ & $21 \mathrm{ab}$ & $25 \mathrm{a}$ & $25 \mathrm{a}$ \\
\hline
\end{tabular}

Xue et al., (2014) found that over application of nitrogen significantly higher $\mathrm{Zn}$ and Fe concentration in grain stover and harvest index

Balakrishnan and Subramanian (2012) reported that Higher Fe concentrations in grains of Mycorrhiza+ plants may be attributed to the hyphal transport of $\mathrm{Fe}$ and besides improved plant available $\mathrm{Fe}$ that may have supported Fe nutrition of maize plants and fortification of grains calcareous (Mycorrhiza- 23.6; Mycorrhiza+ $35.2 \mathrm{mg} \mathrm{kg}-1$ ). Similarly, Zn concentrations (Figure 10) of maize grains were significantly higher for mycorrhizal treatments in both calcareous $\left(36.3 \mathrm{mg} \mathrm{kg}^{-1}\right)$ and non-calcareous $\left(39.7 \mathrm{mg} \mathrm{kg}^{-1}\right.$ ) soils than Mycorrhiza- treatments (Calcareous 22.6; non-calcareous $27.2 \mathrm{mg} \mathrm{kg}^{-1}$ ) (Fig 9). 
Fig: 9. Effect of $\mathrm{Zn}$ and $\mathrm{Fe}$ concentration of grain $\left(\mathrm{mg} \mathrm{kg}^{-1}\right)$ of Arbuscular mycorrhizal fungus inoculated $\left(\mathrm{AMF}^{+}\right)$ and uninoculated $\left(\mathrm{AMF}^{-}\right)$in maize plants.
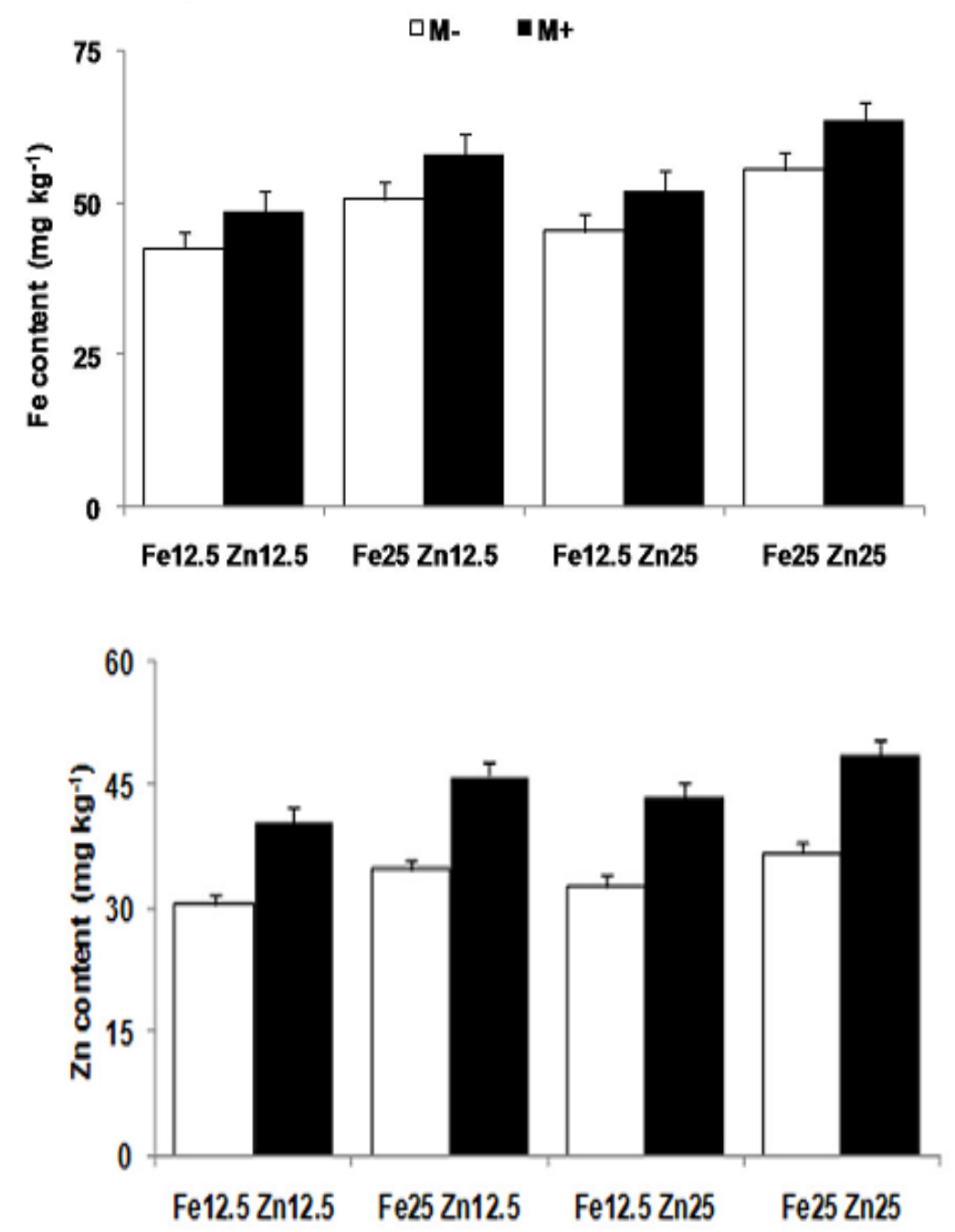

\section{Health problems associated with zinc and iron deficiency:-}

\section{Zn deficiency:-}

* Pregnancy complications, infertility, low birth weight.

* Impairments in brain development and function, decreased nerve conduction, skin lesions.

* Growth faltering, diarrhoea and pneumonia etc.

Fe deficiency:-

* Anaemia and neurodegenerative diseases, mental retardation.

* Impaired immune system, tendency toward bleeding, depression.

* Women and children are at more risk.

\section{Challenges for agronomic biofortification of staple foods:-}

* Setting appropriate target levels for the zinc content of biofortified staple foods.

- Retention of zinc in biofortified staple food.

* Bioavailability of zinc from agronomic biofortified staple food.

* Determining biological impact of biofortified staple crops.

* Creating awareness among the farmers regarding biofortification.

* Increased cost of fertilization. 


\section{Conclusions:-}

* Zinc and iron are essential micronutrients for human health and deficiency of these micronutrients leads to malnutrition and diseases.

* Zinc and iron application increases concentration in produces as well as grain yield under nutrient deficient soil.

- Foliar sprays of $\mathrm{Zn}$ and $\mathrm{Fe}\left(0.5 \% \mathrm{ZnSO}_{4}\right.$ and $\left.\mathrm{FeSO}_{4}\right)$ with two-three times is a most effective level of biofortification in cereals as compare to soil application.

\section{References:-}

1. Aciksoz, S. B., Yazici, A., Ozturk, L. and Cakmak, I. (2011). Biofortification of wheat with iron through soil and foliar application of nitrogen and iron fertilizers. Plant Soil 349:215-25.

2. Alloway, B. J. (2004). Zinc in soils and crop nutrition. IZA Publications. International Zinc Association, Brussels, pp. 1-116.

3. Balakrishnan, N. and Subramanian, K. S. (2012). Mycorrhizal symbiosis and bioavailability of micronutrients in maize grain. Maydica 57: 129-138.

4. Cakmak, I. (2008). Enrichment of cereal grains with zinc: Agronomic or genetic biofortification. Plant Soil 302:1-17.

5. Cakmak, I., Kalayci, M., Kaya, Y., Torun, A. A., Aydin, N., Wang, Y., Arisoy, Z., Erdem, H., Yazici, A., Gokmen, O., Ozturk, 1. and Horst, W. J. (2010). Biofortification and localization of zinc in wheat grain. J. Agri. Food Chem. 58: 9092-9102.

6. Cakmak, I., Pfeiffer, W. H. and McClafferty, B. (2010). Biofortification of durum wheat with zinc: agronomic or genetic biofortification. Cereal Chem. 87: 1-17.

7. Dhaliwal, S. S., Shukla, A .K., Manchanda, J. S. and Kumar, D. (2014). Screening of wheat cultivars and fertifortification with zinc, manganese and iron in low fertility soils of Punjab. VEGETOS 27: 139-45.

8. Fageria, N. K. 2008. The Use of Nutrients in Crop Plants. New York, USA: CRC Press.

9. Hari, Ram, Sohu, V. S., Cakmak, I., Singh, K., Buttar, G. S., Sodhi, G. P. S., Gill, H. S., Bhagat, I., Singh, P., Dhaliwal, S. S. and Mavi, G. S. (2015). Agronomic fortification of rice and wheat grains with zinc for nutritional security. Current Sci. 109: 1-6.

10. Hussain, S., Maqsood, M. A. and Rahmatullah (2010). Increasing grain zinc and yield of wheat for the developing world: a review. Emir. J. Food Agri. 22: 326-39.

11. Kanwal, S., Rahmatullah, Ranjha, A. M., and Rashid, A. (2010). Zinc partitioning in maize grain after soil fertilization with zinc sulphate. Int. J. Agri. Biol. 12: 299-302.

12. Mohsin, A. U., Ahmad, A. U. H., Farooq, M. and Ullah, S. (2014). Influence of zinc application through seed treatment and foliar Spray on growth, productivity and grain quality of hybrid maize. J. Animal Plant Sci. 24:1494-1503.

13. Phattarakul, N., Rerkasem, B., Li, L. J., Wu, L. H., Zou, C. Q., Ram, H., Sohu, V. S., Kang, B. S., Surek, H., Kalayci, M., Yazici, A., Zhang, F. S. and Cakmak, I. (2012). Biofortification of rice grain with zinc through zinc fertilization in different countries. Plant Soil 361:131-41.

14. Prasad, R., Shivay, Y. S. and Kumar, D. (2014). Agronomic biofortification of cereal grains with iron and zinc. Adv. Agron. 125: 55-91.

15. Prasad, R., Shivay, Y. S., and Kumar, D. (2013). Zinc fertilization of cereals for increased production and alleviation of zinc malnutrition in India. Agri. Res. 2:111-118.

16. Purakayastha, T. J. and Chhonkar, P. K. (2001). Influence of vesicular-arbuscular mycorrhizal fungi (Glomus etunicatum L.) on mobilization of zinc in wetland rice (Oryza sativa L.). Biol. Fertil. Soils 33:323-327.

17. Shivay, Y. S. and Prasad, R. (2014). Effect of source and methods of zinc application on corn productivity, nitrogen and zinc concentrations and uptake by high quality protein corn (Zea mays). Egyptian J. Biol. 16: 72-78.

18. Shivay, Y. S., Prasad, R., Kaur, R. and Pal, M. (2015). Relative efficiency of zinc sulphate and chelated zinc on zinc biofortification of rice grains and zinc use-efficiency in basmati rice. Proc. Natl. Acad. Sci., India, Sect. B. Biol. Sci. DOI 10.1007/s40011-015-0544-7.

19. Singh, P., Dhaliwal, S. S. and Sadana, U. S. (2013). Iron enrichment of paddy grains through ferti-fortification. J. Res. Punjab Agric. Univ. 50: 32-38.

20. Stewart, C. P., Dewey, K. G., Ashoran, P., (2010). The undernutrition epidemic: an urgent health priority. Lancet 375, 282. 
21. Wei, Y., Shohag, M. J. I. and Yang, X. (2012). Biofortification and bioavailability of rice grain zinc as affected by different forms of foliar zinc fertilization. PLoS ONE 7: e45428. doi:10.1371/journal.pone.0045428.

22. White, P. J. and M. R. Broadley. (2005). Biofortifying crops with essential mineral elements. Trends Plant Sci. 10:586-593.

23. White, P. J. and Broadley, M. R. (2009). Biofortification of crops with seven mineral elements often lacking in human diets -iron, zinc, copper, calcium, magnesium, selenium and iodine. New Phytol. 182:49-84.

24. Xue, Y., Yue, S., Zhang, W., Liu, D., Cui, Z., Chen, X., Ye, Y. and Zou, C. (2014). Zinc, iron, manganese and copper uptake requirement in response to nitrogen supply and the increased grain yield of summer maize. PLos ONE 9: e93895. doi:10.1371/journal.pone.0093895.

25. Zou, C Q., Zhang, Y. Q., Rashid, A., Ram. H., Savasli, E., Arisoy, R. Z., Ortiz-Monasterio, I., Simunji, S., Wang, Z. H., Sohu, V., Hassan, M., Kaya, Y., Onder, O., Lungu, O., Mujahid, M. Y., Joshi, A. K., Zelenskiy, Y., Zhang, F. S. and Cakmak, I. (2012). Biofortification of wheat with zinc through zinc fertilization in seven countries. Plant Soil 361:119-130. 